\title{
Digital possibilities of the reconstruction of machine parts
}

\author{
Piotr Paszta ${ }^{1, *}$ \\ ${ }^{1}$ Czestochowa University of Technology, Institute of Mechanical Technologies, Al. Armii Krajowej \\ 21, 42-201 Czestochowa, Poland
}

\begin{abstract}
A rapid and continuous development of the machinery and equipment manufacturing capabilities is currently going on. Using CAx programs, complex elements can be made in a straightforward and very fast manner. The creation and use of spatial scanners, photogrammetric methods and spatial modelling is intensively developing, too. A complete object can be produced without the help of tactile methods, using professional 3D scanners, scanners of one's own construction, a camera, or even a cell phone with an in-built camera. The article has described the capabilities of a 3D scanner, verified its accuracy, and has also discussed the capabilities of photogrammetric methods to reconstruct machine parts.
\end{abstract}

Keywords: 3D scanner, Mesh 3D, Geomagic Studio, photogrammetric method

\section{Introduction}

In the traditionally understood engineering, the development of a technological process starts with an idea and preparation of sketches and the development of an assembly drawing or a 3D model using CAx methods, and only then, on this basis, the working drawings of the product are prepared to be used for making the physical object.

By contrast, reverse engineering relies on the existing object and converts analogue data into a digital form amenable to subsequent analysis by computer systems. Using CAx software and fast prototyping methods it is possible to copy and manufacture complex elements or improve existing ones. Very often it is necessary to replicate objects that already physically exist, but there is no their detailed technical documentation, or they have been manufactured manually without the prior preparation of documentation. This practice is pursued in the aircraft industry, in the manufacture of cars, machine parts, in biomedical engineering or the design of coins and medals. Electronic documentation is also created from finished products to prepare the production of replicas or reproduce worn parts.

Demand has arisen for simple-to-use and cheap solutions that would provide the capability to map surrounding us objects into numerical models.

\footnotetext{
*Corresponding author: paszta@itm.pcz.pl

Reviewers: Piotr Krawiec, Josef Soukup
} 
Such models could be changed and duplicated using numerically controlled machine tools and 3D printers. Reconstruction engineering methods are gaining increasing popularity, also thanks to numerous descriptions in generally available publications $[1,2,5]$.

The need for having access to expensive instrumentation is becoming a barrier to the mapping of objects. During mapping an object, a cloud of points is obtained, which represents the scanned object. It is the basis for further processing. The creation of the correct model through the digitalization process is not an easy task, as it requires a big expenditure of time and the use of professional equipment [16-18].

\section{The Scan3D Universe scanner SMARTTECH}

\subsection{Technical specification}

The Scan3D Universe scanner is a mobile and universal object scanner used in reverse engineering. It is characterized by high precision and the capability to scan an object along with its texture. Overall dimensions that can be scanned by this device range from 20 millimetres to 3 metres. For larger elements, special markers are used, which are stuck onto the element to facilitate subsequent combining individual point clouds.

The system works in two resolution modes what allows user to optimize data volume while scanning big objects, and enhance the probing resolution for highly detailed parts such as threats or mounting holes. Possibility to integrate 3D scanner with high-end software for reverse engineering allows automatic data processing from a cloud of points, through mesh into parametric CAD model and also for fast quality control.

The scanner uses white LED light source technology what is additional guarantee of non-invasive measurement. During 3D scanning process user obtains information about object's geometry (XYZ coordinates) and realistic representation of texture in every measured point (RGB in each XYZ point). High quality and high resolution of color detectors used in the device assures that measurement is made with high precision and even the small details, can be seen clearly.

Dedicated measurement and post processing software integrated with scan3D UNIVERSE is a complex solution which enables end user to prepare 3D documentation process and perform virtual research such as cuts or modeling of missed parts of the scanned object. Multiple export formats as well as: standard raw data format allows the data to be used in all popular CAD or 3D graphical software such as: Maya, ZBrush or 3Dmax, SolidWorks [6]. User can easily share the results with other researchers thanks to a free SMARTTECH3Dmeasure Viewer software [23].

\subsection{Scanning within the program Mesh3D}

As the first object to be scanned, a solid of revolution, specifically a chess pawn, was chosen, which was made on a CNC CBKO OSA 200 turning lathe. As the object's surface was too shiny, it was covered with a thin layer of chalk, which substantially reduced the light reflection. The object was composed of seven clouds of points.

The obtained point cloud had to be cleared of the excess of points generated as a result of scanning of part of the rotary table. Geomagic Studio, the software dedicated by the scanner manufacturer, was used for this purpose.

To show defects in a greater detail and to enable their repair, the surface was transferred to the Autodesk Meshmixer program. 
The mapping of the solid could be assessed as accurate; all sharp edges and roundings were visible. The solid had high surface roughness. This was caused by the method of applying the surface coating to eliminate the sheen. For measuring the dimensional accuracy, the diameter of the hollow in the object's lower part, the diameter of the convex part ended with a sharp edge, and the diameter of the semicircle at the pawn's top were used (Fig. 1).
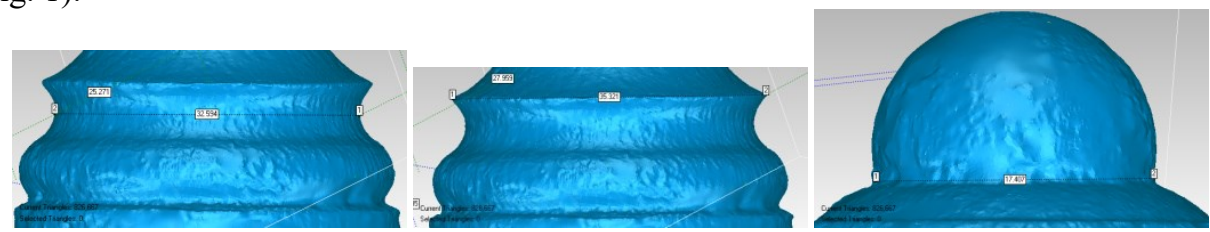

Fig. 1. Measurement of the pawn diameters

The dimensions of the object were measured using an electronic slide caliper with an accuracy of $0.01 \mathrm{~mm}$. The object's dimensions obtained in the program had an accuracy of $0.001 \mathrm{~mm}$ and were rounded off to $0.01 \mathrm{~mm}$. Measurements with the electronic slide caliper and measurements done within the Geomagic Studio software were repeated three times for each dimension, and then averaged. The measurement results are shown in Table 1.

Table 1. Results of object measurements

\begin{tabular}{|c|c|c|c|}
\hline Measurement type & $\begin{array}{c}\text { Measurement from } \\
\text { the program } \\
{[\mathbf{m m}]}\end{array}$ & $\begin{array}{c}\text { Slide caliper } \\
\text { measurement } \\
{[\mathbf{m m}]}\end{array}$ & $\begin{array}{c}\text { Dimension } \\
\text { difference } \\
{[\mathbf{m m}]}\end{array}$ \\
\hline $\begin{array}{c}\text { Hollow diameter } \\
\text { measurement }\end{array}$ & 32.62 & 32.55 & 0.07 \\
\hline $\begin{array}{c}\text { Convex part } \\
\text { diameter }\end{array}$ & 35.35 & 35.29 & 0.06 \\
\hline $\begin{array}{c}\text { Semicircular top } \\
\text { diameter }\end{array}$ & 17.41 & 17.28 & 0.13 \\
\hline
\end{tabular}

The next scanned element was a motorcycle piston. The piston had a larger number of details and defects, which were more difficult to map. The piston surface was also shiny, so prior to scanning it was covered with a titanium oxide layer to prevent reflexes from occurring on the object's surface. The scanning procedure did not deviate significantly from the procedure of scanning the previous element. The finished cloud of points was made up of 7 individual scans that were combined automatically in the Mesh3D program. The final result of scanning and processing is shown in Figure 2.
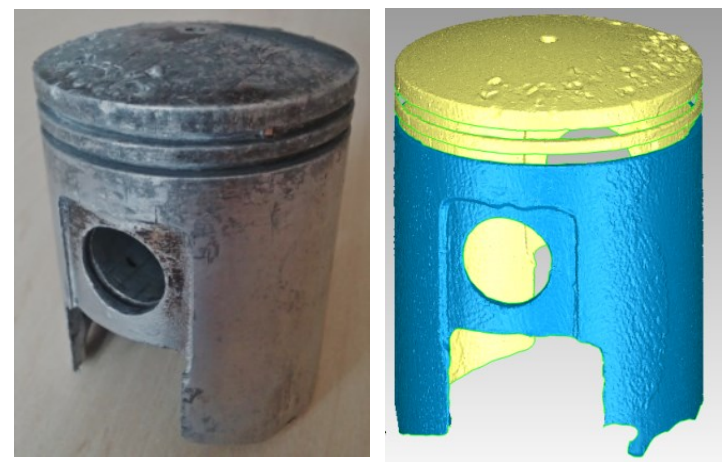

Fig. 2. The motorcycle piston and the scanned piston 
For the verification of the dimensional accuracy of the generated object, the diameter of the piston pin boss hole and the width of the piston ring recess were used. The measurement results are shown in Table 2.

Table 2. Results of object measurements

\begin{tabular}{|c|c|c|c|}
\hline Measurement type & $\begin{array}{c}\text { Measurement from } \\
\text { the program } \\
{[\mathbf{m m}]}\end{array}$ & $\begin{array}{c}\text { Slide caliper } \\
\text { measurement } \\
{[\mathbf{m m}]}\end{array}$ & $\begin{array}{c}\text { Dimension } \\
\text { difference } \\
{[\mathbf{m m}]}\end{array}$ \\
\hline $\begin{array}{c}\text { Pin boss hole } \\
\text { diameter }\end{array}$ & 18.65 & 18.56 & 0.09 \\
\hline $\begin{array}{c}\text { Piston ring recess } \\
\text { width }\end{array}$ & 2.34 & 2.25 & 0.09 \\
\hline $\begin{array}{c}\text { Piston skirt } \\
\text { diameter }\end{array}$ & 60.77 & 60.87 & -0.10 \\
\hline
\end{tabular}

The Geomagic Studio provides the capability to inscribe an element or its part into the ideal standard. Thanks to this, we are able to verify whether the solid has been mapped correctly or not, and to check for its possible distortions (Fig. 3).

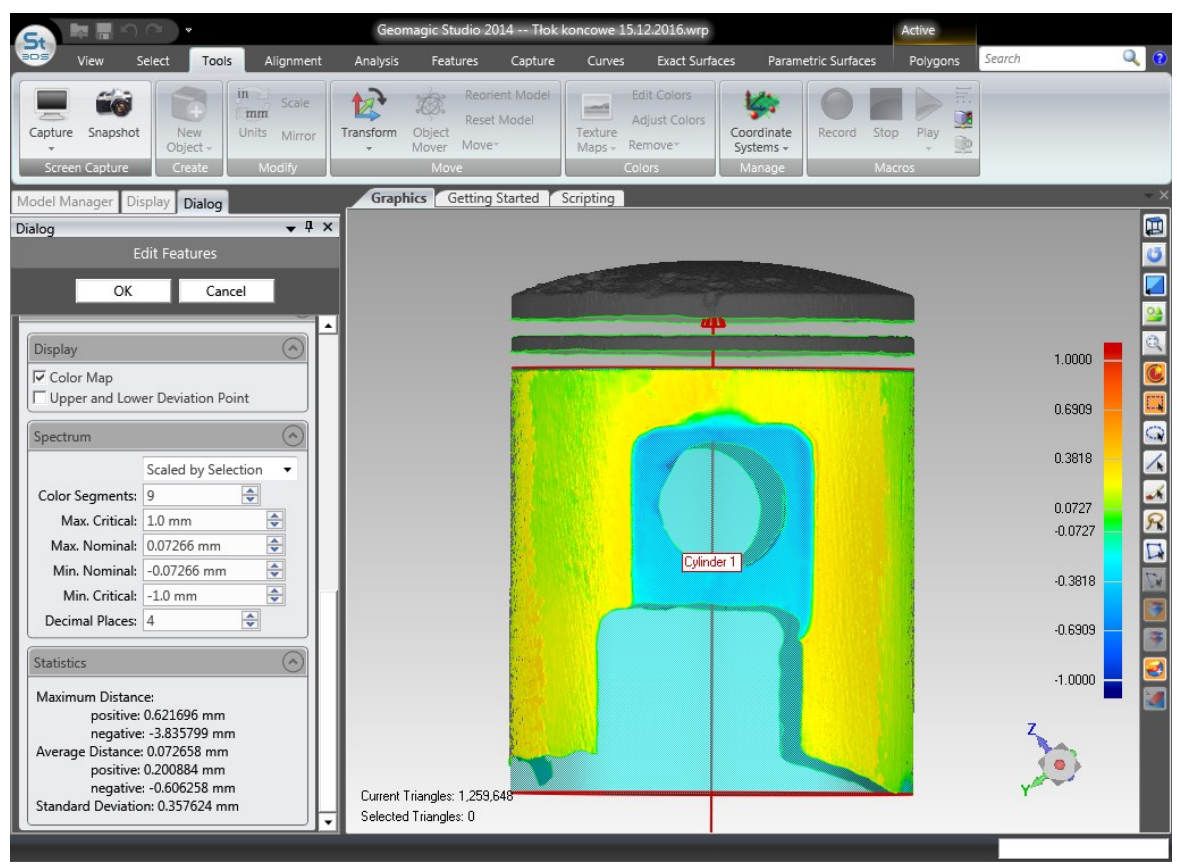

Fig. 3. The inscription of the solid into the ideal standard

The figure shows the piston skirt inscribed into the ideal cylinder of a diameter of 60 $\mathrm{mm}$ and a length of $64 \mathrm{~mm}$. The range of deformations given in millimetres was scaled so that the visible colours clearly reflect the deformations. This range was set to $\pm 1 \mathrm{~mm}$ relative to the standard. Green and yellow colours distinctly predominate in the figure. This means that the difference between the examined object and the standard ranges between 0 and $0.2 \mathrm{~mm}$. No major distortions of the skirt shape were noticed. 


\section{Scanning using a smartphone and a digital camera}

Scanning an object using a digital camera or a phone with an in-built camera boils down to taking a series of accurate shots around the object. The number of photos needed for mapping the object depend on the type and degree of complexity of the object's surface. The object's photos are subsequently opened by the program, which analyzes them and searches for shared points on each of the photos, and then combines them to form a threedimensional object.

\subsection{Autodesk ReMake}

A program for generating three-dimensional objects from photographs is ReMake. The object had to be coated with a layer that would prevent light reflection from the object's surface. To verify the dimensional accuracy of the object generated based on the photos, the same objects that had been scanned with the Scan3D Universe scanner were used. The first object was a chess pawn, around which a series of 30 snapshots were taken. The program offered the capability to choose the mode that determined the location of processing data. It was decided to run the program in the online mode. In this mode, the photos were automatically sent onto the Autodesk server, where the data in the form of photos were processed into a finished three-dimensional object in the form of a grid of triangles with a superimposed texture. The measurement results are shown in Table 3.

Table 3. Results of object measurements

\begin{tabular}{|c|c|c|c|}
\hline Measurement type & $\begin{array}{c}\text { Measurement from } \\
\text { the program } \\
{[\mathbf{m m}]}\end{array}$ & $\begin{array}{c}\text { Slide caliper } \\
\text { measurement } \\
{[\mathbf{m m}]}\end{array}$ & $\begin{array}{c}\text { Dimension } \\
\text { difference } \\
{[\mathbf{m m}]}\end{array}$ \\
\hline $\begin{array}{c}\text { Hollow diameter } \\
\text { measurement }\end{array}$ & 33.24 & 32.55 & 0.69 \\
\hline $\begin{array}{c}\text { Convex part } \\
\text { diameter }\end{array}$ & 35.95 & 35.29 & 0.66 \\
\hline $\begin{array}{c}\text { Semicircular top } \\
\text { diameter }\end{array}$ & 16.67 & 17.28 & -0.61 \\
\hline
\end{tabular}

In a manner similar to generating the pawn in the Autodesk ReMake program, the piston model was created. It was made up of 54 photos taken around the object. The program only shows 38 camera positions, because a substantial portion of the base and other elements not belonging to the solid have been removed. The program was not able to detect shared points in some photos. In locations of a larger number of details, such as the boss hole, the density of photos was increased to more accurately map the hole. These hollows are only visible down to a certain depth, were the test stand lighting would reach. The boss was not managed to be mapped across the whole piston width. The piston ring recesses are not of equal depth over their whole length. In some places, a recess equals the piston skirt diameter, which is visible after removing the texture from the object (Fig. 4). All solid contours are visible, and the surface adequately renders the object's shape. In the lower part of the solid, the location of the rectangular cut-out has side walls which, in spite of light poorly reaching the piston inside, have been well reflected. For further measurements, the surface was exported to the Geomagic Studio program. The measurement results are shown in Table 4. 
Table 4. Results of object measurements

\begin{tabular}{|c|c|c|c|}
\hline Measurement type & $\begin{array}{c}\text { Measurement from } \\
\text { the program } \\
{[\mathbf{m m}]}\end{array}$ & $\begin{array}{c}\text { Slide caliper } \\
\text { measurement } \\
{[\mathbf{m m}]}\end{array}$ & $\begin{array}{c}\text { Dimension } \\
\text { difference } \\
{[\mathbf{m m}]}\end{array}$ \\
\hline $\begin{array}{c}\text { Pin boss hole } \\
\text { diameter }\end{array}$ & 18.29 & 18.56 & -0.22 \\
\hline $\begin{array}{c}\text { Piston ring recess } \\
\text { width }\end{array}$ & 2.42 & 2.25 & -0.27 \\
\hline $\begin{array}{c}\text { Piston skirt } \\
\text { diameter }\end{array}$ & 60.65 & 60.87 & 0.23 \\
\hline
\end{tabular}

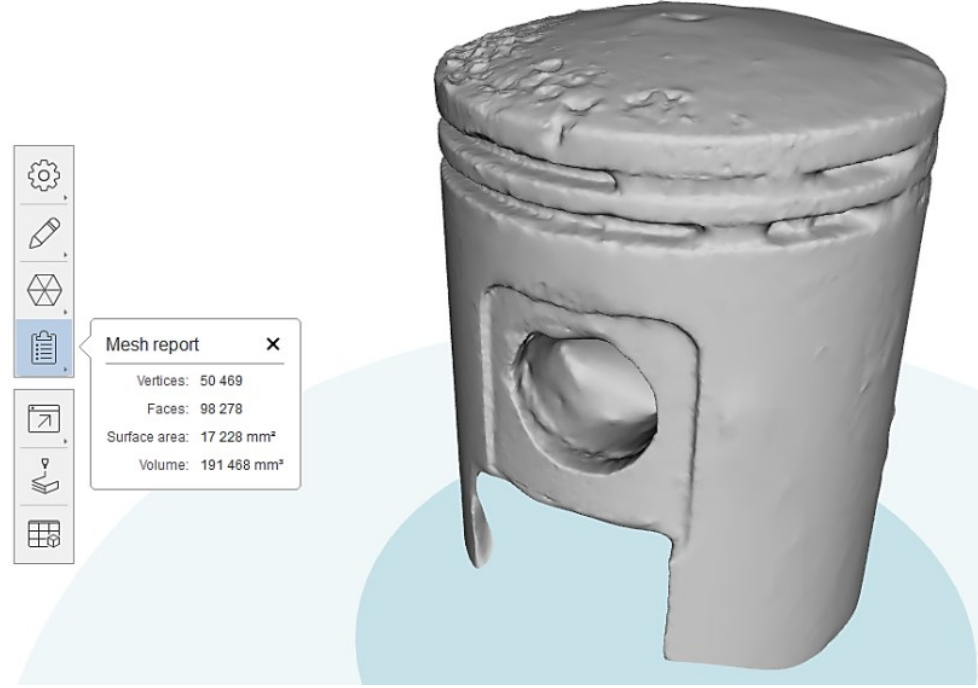

Fig. 4. The piston generated in the Autodesk Remake program

As a scanning object with a much greater number of details and parts protruding outside the solid contour, which could not be scanned with a Scan3D optical scanner due to large overall dimensions, an internal combustion engine block was selected, complete with its valve cover and oil sump. For photographing the object, an LG G2 smartphone with a 12 Mpix camera of a focal length of $4 \mathrm{~mm}$ and an Olympus SP-600UZ digital camera with a 12 Mpix CCD matrix and a lens of a local length of 5-75 $\mathrm{mm}$ were used, respectively.

When preparing the object for being photographed, shiny locations that might have not been mapped were not cleaned. By photographic the object with the LG smartphone camera, 180 photos were taken around the engine, while by photographic the object with the Olympus digital camera, 95 photos were produced. After creating separate models from either photo series in the Autodesk ReMake program, the accuracy of mapping of individual photo details was compared (Fig. 5). The results are shown in Table 5. 


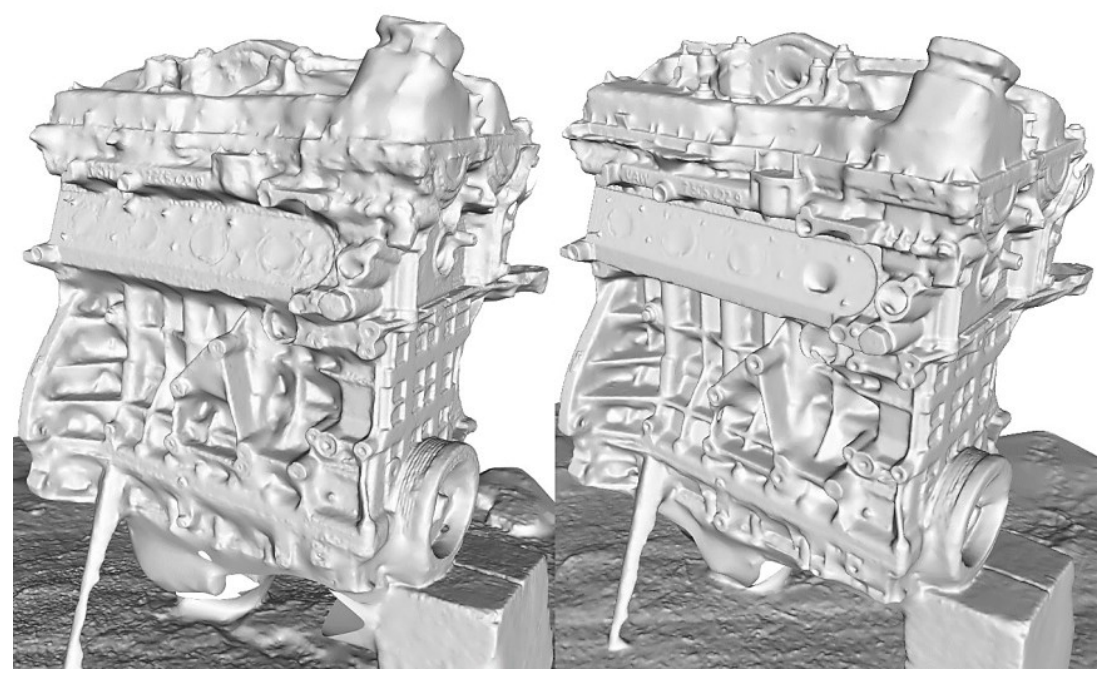

Fig. 5. Comparison of the models created from the series of photos taken using the LG G2 smartphone (on the left) and the Olympus SP-600UZ camera (on the right)

Table 5. The results of engine part measurements

\begin{tabular}{|c|c|c|c|c|c|}
\hline \multirow{2}{*}{$\begin{array}{c}\text { Measurement } \\
\text { type }\end{array}$} & \multicolumn{2}{|c|}{$\begin{array}{c}\text { Measurement from the } \\
\text { program } \\
\text { [mm] }\end{array}$} & \multicolumn{2}{c|}{$\begin{array}{c}\text { Slide } \\
\text { caliper } \\
\text { measurement } \\
\text { [mm] }\end{array}$} & \multicolumn{2}{|c|}{$\begin{array}{c}\text { Dimension difference } \\
\text { [mm] }\end{array}$} \\
\cline { 2 - 3 } & $\begin{array}{c}\text { Smatrphone } \\
\text { LG G2 }\end{array}$ & $\begin{array}{c}\text { Olympus } \\
\text { SP-600UZ }\end{array}$ & $\begin{array}{c}\text { Smatrphone } \\
\text { LG G2 }\end{array}$ & $\begin{array}{c}\text { Olympus } \\
\text { SP-600UZ }\end{array}$ \\
\hline $\begin{array}{c}\text { Exhaust } \\
\text { manifold } \\
\text { screw } \\
\text { diameter }\end{array}$ & 8.14 & 7.8 & 6.98 & 1.16 & 0.91 \\
\hline $\begin{array}{c}\text { Oil filler } \\
\text { plug } \\
\text { width }\end{array}$ & 70.51 & 67.6 & 68.73 & 1.78 & -1.09 \\
\hline $\begin{array}{c}\text { Starter } \\
\text { opening } \\
\text { diameter }\end{array}$ & 78.84 & 75.1 & 76.27 & 2.57 & -1.18 \\
\hline $\begin{array}{c}\text { V-belt pulley } \\
\text { diameter }\end{array}$ & 139.78 & 140.1 & 141.42 & -1.64 & -1.3 \\
\hline $\begin{array}{c}\text { Exhaust port } \\
\text { diameter }\end{array}$ & 43.35 & 40.9 & 42.19 & 1.16 & -1.28 \\
\hline
\end{tabular}

\subsection{Agisoft Photoscan}

For comparison purposes, it was decided to use the software by Agisoft. The Photoscan program is an extensive tool for creating dense point clouds, orthophotomaps, model textures, the digital surface model and the digital land model.

This program does not offer the capability to draw on the computing power of external servers. It only uses the device on which it is installed, therefore it has high hardware demands. On account of the parameters on the computer on which the program was installed, the number of photos subjected to processing was limited to 70 . For the pawn, the program detected shared points only in ten out of thirty photos. Distortions of the upper pawn part were visible; however, the remaining part was reproduced in a manner sufficient 
for subsequent measurements. The measurement was taken in the same locations of the solid, as in the case of mapping in the ReMake program. The results are shown in Table 6.

Table 6. Results of object measurements

\begin{tabular}{|c|c|c|c|}
\hline Measurement type & $\begin{array}{c}\text { Measurement from } \\
\text { the program } \\
\text { [mm] }\end{array}$ & $\begin{array}{c}\text { Slide caliper } \\
\text { measurement } \\
\text { [mm] }\end{array}$ & $\begin{array}{c}\text { Dimension } \\
\text { difference } \\
{[\mathbf{m m}]}\end{array}$ \\
\hline $\begin{array}{c}\text { Hollow diameter } \\
\text { measurement }\end{array}$ & 32.91 & 32.55 & 0.36 \\
\hline $\begin{array}{c}\text { Convex part } \\
\text { diameter }\end{array}$ & 35.68 & 35.29 & 0.39 \\
\hline $\begin{array}{c}\text { Semicircular top } \\
\text { diameter }\end{array}$ & 17.63 & 17.28 & 0.35 \\
\hline
\end{tabular}

In the case of creating the piston model, the program was able to detect shared point in 36 out of 54 photos, and the processing lasted 4 hours. As a result, however, a dense point cloud was obtained. After creating the grid of triangles and the analysis of the surface (Fig. 6), it can be stated that the object has been mapped correctly; the piston skirt is smooth, without sharp edges, and has no defects. The program has been very successful in creating the inner bush part and the ring recesses, although they are deformed in some places. The results are shown in Table 7.
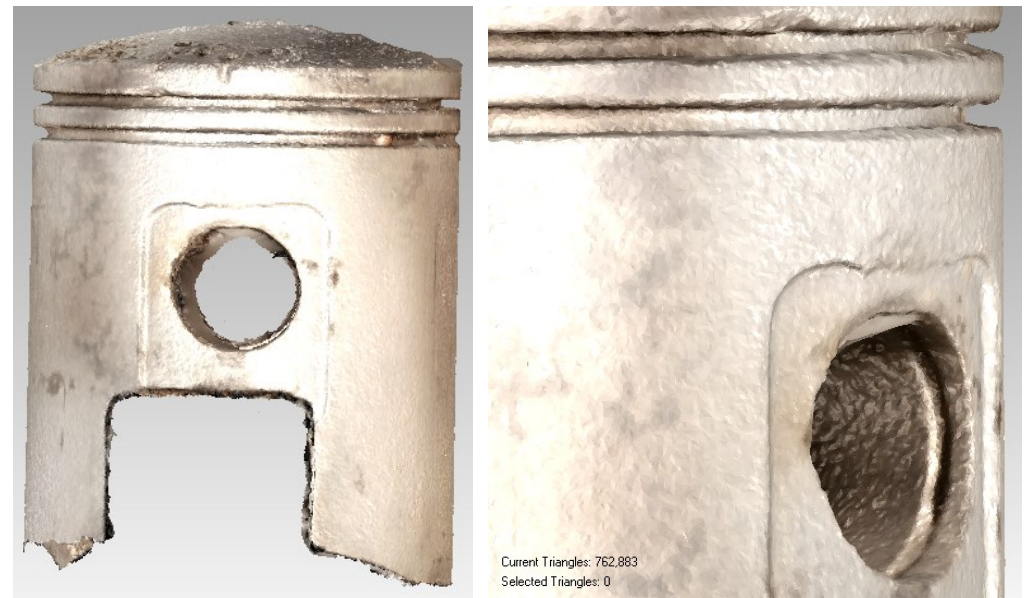

Fig. 6. The generated surface and the mapping of the piston recesses

Table 7. Results of object measurements

\begin{tabular}{|c|c|c|c|}
\hline Measurement type & $\begin{array}{c}\text { Measurement from } \\
\text { the program } \\
\text { [mm] }\end{array}$ & $\begin{array}{c}\text { Slide caliper } \\
\text { measurement } \\
\text { [mm] }\end{array}$ & $\begin{array}{c}\text { Dimension } \\
\text { difference } \\
{[\mathbf{m m}]}\end{array}$ \\
\hline $\begin{array}{c}\text { Pin boss hole } \\
\text { diameter }\end{array}$ & 18.38 & 18.56 & -0.18 \\
\hline $\begin{array}{c}\text { Piston ring recess } \\
\text { width }\end{array}$ & 2.39 & 2.25 & 0.14 \\
\hline $\begin{array}{c}\text { Piston skirt } \\
\text { diameter }\end{array}$ & 60.67 & 60.87 & -0.2 \\
\hline
\end{tabular}

In the case of generating the engine block, the program needed too much RAM memory to generate the model from the series of 180 smartphone photos. For the creation of the 
engine block model, only the Olympus camera photo series was used, which was curtailed to 69 photos.

After generating the surface and the compact texture, the object was analyzed for the accuracy of reproduction of individual details (Fig. 7). The valve cover, in spite of the dark colour, was correctly reconstructed. All cavities, protruding parts and recesses were reproduced correctly. Special consideration was given to the protruding threaded pins in the area of the exhaust gas outlet, which were largely mapped. In the case of the ReMake program, the pins were not created at all. Prior to proceeding with dimensional analysis, the solid should have been rescaled. The scaled object was subjected to dimensional analysis, whose results are shown in Table 8. The dimensional analysis was made in the Agisoft Photoscan program.
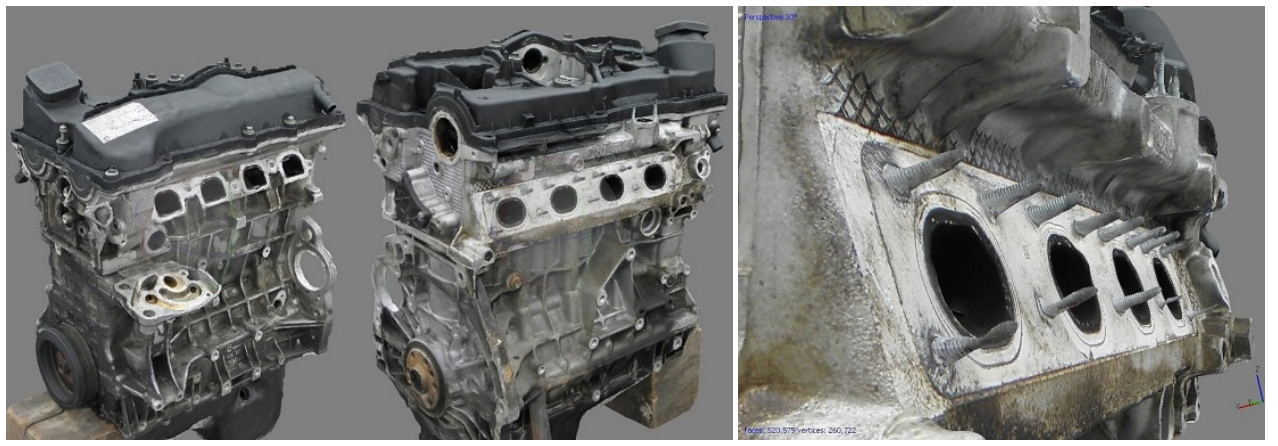

Fig. 7. The object's surface along with the generated texture and the reproduction of details

Table 8. The results of engine part measurements

\begin{tabular}{|c|c|c|c|}
\hline Measurement type & $\begin{array}{c}\text { Measurement from } \\
\text { the program } \\
{[\mathbf{m m}]}\end{array}$ & $\begin{array}{c}\text { Slide caliper } \\
\text { measurement } \\
{[\mathbf{m m}]}\end{array}$ & $\begin{array}{c}\text { Dimension } \\
\text { difference } \\
{[\mathbf{m m}]}\end{array}$ \\
\hline $\begin{array}{c}\text { Exhaust manifold } \\
\text { screw diameter }\end{array}$ & 7.51 & 6.98 & 0.53 \\
\hline $\begin{array}{c}\text { Oil filler plug } \\
\text { width }\end{array}$ & 67.97 & 68.73 & -0.76 \\
\hline $\begin{array}{c}\text { Starter opening } \\
\text { diameter }\end{array}$ & 78.85 & 76.27 & 1.18 \\
\hline $\begin{array}{c}\text { V-belt pulley } \\
\text { diameter }\end{array}$ & 140.35 & 141.42 & -1.07 \\
\hline $\begin{array}{c}\text { Exhaust port } \\
\text { diameter }\end{array}$ & 42.81 & 42.19 & 0.62 \\
\hline
\end{tabular}

The greatest difference between the dimension in the program and the measured dimension was $1.07 \mathrm{~mm}$. This is a very good result, considering the size of the whole object. Both smaller and bigger elements were measured to check whether the deviations had an increasing trend with decreasing dimension, or not.

\section{Analysis of the measurement results and conclusions}

Comparison of the accuracy of the Smarttech Scan3D high-class optical scanner and the software programs Autodesk ReMake and Agisoft Photoscan used for the creation of threedimensional models from photographs has found that the scanner has a higher accuracy, which makes it a device suitable for the accurate reproduction of objects and for making indepth dimensional analyses. Generating surfaces using a smartphone or a digital camera 
and appropriate software is a solution suitable for tasks that do not require high accuracy. The Scan3D scanner is large and requires many peripheral elements, therefore it fulfils its role in stationary applications. A smartphone or a camera is small and handy, and anybody can take it with him/her anywhere. Table 9 compares the accuracy of three-dimensional models, depending on the hardware and software used.

Table 9. Comparison of the accuracy

\begin{tabular}{|c|c|c|c|}
\hline \multirow{2}{*}{ Object } & \multicolumn{3}{|c|}{ Mean absolute error of measurement [mm] } \\
\cline { 2 - 4 } & Scan3D & Autodesk ReMake & Agisoft Photoscan \\
\hline Pawn & 0.086 & 0.65 & 0.37 \\
\hline Piston & 0.093 & 0.24 & 0.17 \\
\hline Engine block (LG G2) & - & 1.66 & - \\
\hline Engine block (Olympus) & - & 1.15 & 0.83 \\
\hline
\end{tabular}

When analyzing the mean absolute errors it can be noticed that the Scan3D is the most accurate. Its error is around $0.09 \mathrm{~mm}$. The engine block was not scanned with a scanner due to its large overall dimensions and no possibility of transferring the scanner. The ReMake program creates a surface automatically. During processing, we do not have access to any options. The results in the table show a mean error of $0.45 \mathrm{~mm}$ for small objects. For larger overall dimensions, the accuracy is dependent on the type of equipment used for photographing. Using the smartphone for photographing the object, the mean error amounted to $1.66 \mathrm{~mm}$. This is a very good results, considering the large size of the engine block. When the photos were taken with the Olympus digital camera, the mean error decreased to $1.15 \mathrm{~mm}$. This means that the accuracy depends largely on the parameters and optics of the photographic equipment used. To compare the accuracy of the software, it was decided to create the models of the same objects within the Photoscan program. The mean error results are smaller, compared to the ReMake program. Photoscan has many settings for photograph processing and enables the selection of processing quality at each of the four stages: searching for shared points in the photos, creation of a cloud of points and creation of a surface and texture. Thanks to this, it is possible to reproduce objects more accurately.

The duration of the preparation of object models, as dependent on the type of software and hardware used, is shown in Table 10.

Table 10. The duration of model preparation

\begin{tabular}{|c|c|c|c|}
\hline \multirow{2}{*}{ Object } & \multicolumn{3}{|c|}{ The duration of model preparation [min] } \\
\cline { 2 - 4 } & Scan3D & Autodesk ReMake & Agisoft Photoscan \\
\hline Pawn & 140 & 30 & 120 \\
\hline Piston & 160 & 40 & 150 \\
\hline Engine block (LG G2) & - & 60 & - \\
\hline Engine block (Olympus) & - & 80 & 860 \\
\hline
\end{tabular}

The results indicate large differences in the duration of model preparation. Taking into account the small objects, the duration of the preparation of models from the Scan3D scanner and the Photoscan program is similar, amounting to about 3 hours. The ReMake program creates small object models within a time shorter by a factor of 5 .

\section{References}

1. D. Oniszczuk, Wykorzystanie skanera $3 D$ w pomiarach przedmiotów o złożonej geometrii. Przegląd Mechaniczny 2, 41-45 (2012) 
2. F. Bernardini, H Rushmeier. The 3D Model Acquisition Pipeline. Computer Graphics Forum, 21, 149-72 (2002)

3. K. Karbowski. Podstawy rekonstrukcji elementów maszyn i innych obiektów $w$ procesach wytwarzania. Monografia nr 367, Kraków (2008)

4. M. Wylezoł, Inżynieria odwrotna $w$ doskonaleniu konstrukcji. Modelowanie Inżynierskie 43, 485-490 (2006)

5. M. Wylezoł. Metodyka modelowania na potrzeby inżynierii rekonstrukcyjnej. Monografia nr 428, Gliwice, Politechnika Śląska (2013)

6. P. Boral, T. Nieszporek, R. Gołębski, The welded CNC machine tool frame. MATEC Web of Conferences, 157 (2018)

7. K. E. Oczoś, I. Cena, Rapid Inspection metody pomiarowo-kontrolne adekwatne do rapid-technologii. Mechanik, 3 (2008)

8. M. Wyleżoł, Zastosowanie inżynierii odwrotnej oraz technik Rapid Tooling w rozwoju produktu. Mechanik, 1 (2008)

9. A. Werner, Ocena dokładności realizacji procesu inżynierii odwrotnej obiektu przestrzennego. PAR, 5 (2012)

10. I. Wróbel, Inżynieria odwrotna jako metoda tworzenia cyfrowych modeli przedmiotów o skomplikowanych ksztattach. Mechanik, 3 (2010)

11. R. Hartley, A. Zisserman, Multiple View Geometry in Computer Vision. Cambridge University (2004)

12. J. Mac, R. Grzechowiak, Zastosowanie metod fotogrametrycznych $w$ badaniach pojazdów rolniczych. Technika Rolnicza Ogrodnicza Leśna, 3 12-15 (2014)

13. L. Wiatr, Opracowanie fotogrametrycznych zdjęć lotniczych, satelitarnych i naziemnych. ITE - Państwowy Instytut Badawczy, Radom (2007)

14. A. Wójcicki, S. Herma, Fotogrametria jako alternatywna metoda modelowania obiektow 3D. KIP, ATH, Bielsko-Biała (2009)

15. D. Zawieska, Wieloobrazowe dopasowanie zdjęć bliskiego zasięgu do automatycznej rekonstrukcji fotorealistycznych modeli 3D. Oficyna Wydawnicza PW, Warszawa (2013)

16. P. Paszta, Budowa i sprawdzenie laserowego skanera $3 D$ opartego na kontrolerze Microsoft Kinect. TTS, 12 (2015)

17. P. Paszta, R. Gołębski, Construction and Verification the Accuracy of Laser Scanner 3D. Mechanik, 7 (2014)

18. P. Paszta, R. Gołębski, Mapping of objects using a 3D laser scanner. Logistyka, 6 (2014)

19. www.agisoft.com

20. www.autodesk.com

21. www.geomagic.com

22. www.photomodeler.com

23. www.smarttech3dscanner.com 